\title{
Observation and Documentation of Medicinal Plant Diversity of Seoni District, Madhya Pradesh Used in Traditional Medicine for Skin Diseases
}

\author{
Praveen Parate and Naureen S. Khan* \\ Department of Life science, Dr. C.V. Raman University \\ Kargi Road, Kota, Bilaspur (C.G.), India
}

\section{ABSTRACT}

The paper reports ethnobotanical study based on the traditional medicinal plants used by the local population for the treatment of skin diseases. The main aim of the study was to observe and document medicinal plants of Seoni district, Madhya Pradesh. In the present study exhaustive field exploration and study was conducted to survey medicinal plants originating in eight tehsils of Seoni District from November 2019 to November 2020. The ethnobotanical data was collected using field work and survey method by performing semi-structured interviews and group discussions with the traditional healers and the local population. The ethnomedicinal survey yielded documentation of 97 plant species belonging to 43 families and 90 genera. The most dominant families observed in the study were Fabaceae, Cucurbitaceae, Poaceae, Moraceae, Caesalpinaceae, Rutaceae, Apiaceae, Anacardiaceae, Zingiberaceae, Chenopodiaceae, Rosaceae, Liliaceae, Arecaceae and Malvaceae. The tribals possess tremendous traditional knowledge of medicinal plants that can be used to cure different ailments. However, urbanization and expansion on agricultural practices have become a major threat to the medicinal plants. Hence, it is of utmost importance to preserve the indigenous knowledge of herbal medicines through identification and systematic documentation. The present study also aims to document the use of traditional herbal medicines of Seoni district that are used for curing skin problems. Conservation of the traditionally important plant species with the help of local population will enhance the ethnomedicinal diversity of the place.

KEY WORDS: SEONI, MADHYA PRADESH, MEDICINAL PLANTS, DOCUMENTATION, HERBAL MEDICINES, CONSERVATION.

\section{INTRODUCTION}

Plants form an integral part of our lives as they provide bioactive compounds and secondary metabolites that can fight several infections (Singh et al., 2020). Medicinal plants are traditionally used in herbal and Ayurvedic

\section{ARTICLE INFORMATION}

*Corresponding author email: nicks30khan@gmail.com Received 10th Oct 2020 Accepted after revision 26th Dec 2020 Print ISSN: 0974-6455 Online ISSN: 2321-4007 CODEN: BBRCBA

Thomson Reuters ISI Web of Science Clarivate Analytics USA and Crossref Indexed Journal

\section{Clarivate
Analytics}

NAAS Journal Score 2020 (4.31)

A Society of Science and Nature Publication, Bhopal India 2020. All rights reserved.

Online Contents Available at: http//www.bbrc.in/

Doi: http://dx.doi.org/10.21786/bbrc/13.15/56 medicines for curing different ailments (Lal and Sahu, 2019). The practice and use of traditional medicine has been conducted throughout the world for healing various human diseases (Hussain et al., 2018; Singh et al., 2020). Tribal population across the globe still depends on the medicinal plants for first aid treatment of cough, cold, fever and other related diseases (Ayyan and Ignacimuthu, 2011). Thus, traditional medicinal practices are a piece of knowledge that is transferred through generations for diagnosis, management and treatment of body ailments (Jima and Megersa, 2018; Vendrapati et al., 2020).

Madhya Pradesh comes in the central part of India and has a rich and diverse bio-geographical area (Lal and Sahu, 2019). Seoni district is located near the Satpura plateau and has a vast store of herbal plants

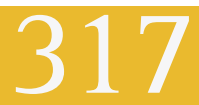


and traditional medicinal knowledge. The area is rich in diverse flora across the district and its medicinal knowledge is still preserved by the herbal healers, vaidya and the tribal population. The Seoni district is divided into eight tehsil places that are Lakhnadaun, Ghansaur, Dhanora, Chhapara, Keolari, Seoni, Barghat and Kurai. The tribal population and the forest dwellers have access to the remote areas of the forests and are mostly dependent on the medicinal plant knowledge for curing several ailments.

Ethomedicinal work in India and across the globe has also been studied and outlined by a number of research scholars such as Mohan et al., (2008); Alyemeni et al., (2010); Ayyanar and Ignacimuthu (2011); Karunamoorthi et al., (2012); De Wet et al., (2013); Rahman (2013); Sharma et al., (2013); Pius et al., (2015); Bandyopadhyay (2017); Hussain et al., (2018); Jima and Megersa (2018); Satpute (2020); Singh et al., (2020); Vendrapati et al., (2020). Similary, Several ethonomedicinal work related to the medicinal flora of Madhya Pradesh has been done by many researchers as Dwivedi et al. (2008); Nath and Khatri (2010); Jatav and Mehta (2013); Ahirwar (2014); Wagh and Jain (2014); Rai (2016); Ahirwar (2017); Ahirwar et al. (2017); Iqbal (2017); Rai (2017); Gwalvanshi and Bishwas (2017); Pal and Patel (2017); Jain et al. (2018); Lal and Sahu (2019). However, in Central India, Seoni district was unexposed to ethonomedicinal survey and documentation of the traditional medicinal flora. Hence, the present study was performed to identify and document the medicinal plant diversity of the eight tehsils of Seoni district and also analyze the use of the medicinal plants in healing skin diseases.

\section{MATERIAL AND METHODS}

Seoni district is situated on North-South area of Satpura Plateau and lies between latitude $2136^{\prime}$ Et 22 57' North and longitude $7919^{\prime}$ and $8017^{\prime}$ East. The total geographical area of Seoni district is $8,758 \mathrm{~km} 2$. For the ethnomedicinal study eight tehsils of Seoni District, Madhya Pradesh namely Lakhnadaun (LD). Ghansaur (GS), Dhanora (DN), Chhapara (CP), Keolari (KL), Seoni $(\mathrm{SN})$, Barghat (BG) and Kurai (KR) were selected (Figure $1 \mathrm{~A})$. The study was performed to identify and document the traditional medicinal flora of the Seoni district. The survey was conducted from November 2019 to November 2020 and plant samples were collected through medicinal information gathered from traditional healers, vaidya and the local tribal population (Figure $1 \mathrm{~B}$ and $\mathrm{C}$ ).

The medicinal information was obtained using interview method and preparation of question design technique and group discussions. Method of cross checking the information through different sources and sampling technique was also followed. The identification of the plant samples was conducted with the help of local tribals of the place and the traditional healers of the locality. Identification of the plant specimens was performed using the Book, Flora of Madhya Pradesh Vol. 1 and Ayurved Jadi Booti Rahasya Vol. 1, literature available through other sources was also referred for the study.
Figure 1: A- Map of Seoni district showing Eight Tehsils (Sampling sites) for collection of Medicinal plants. B and C- Fieldwork and collection of medicinal plants with help of tribals.

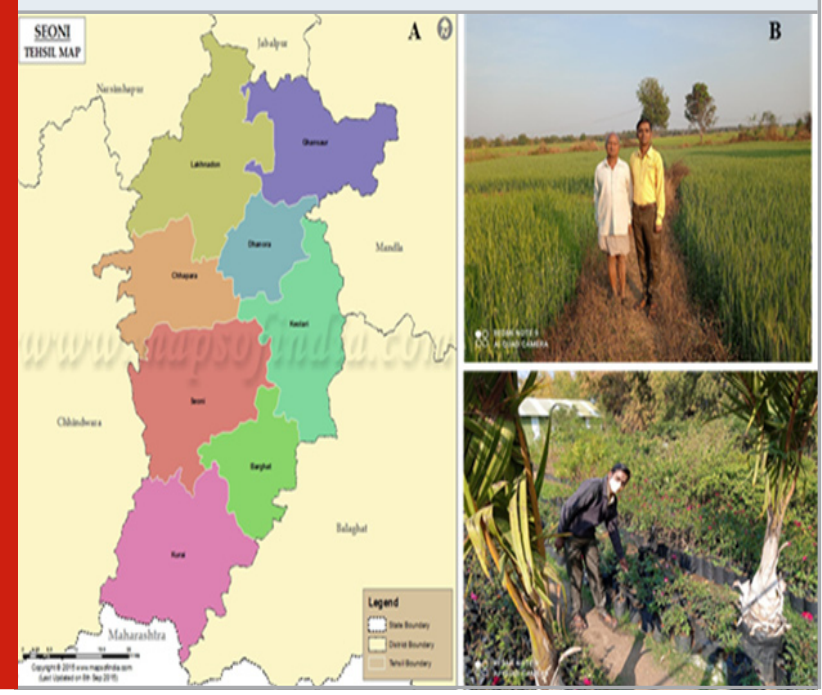

\section{RESULTS AND DISCUSSION}

In the present study, 97 plant species belonging to 43 families and 90 genera have been identified and documented (Table 1). Plants of ethonomedicinal importance were collected from eight tehsils (Lakhnadaun, Dhanora, Ghansaur, Chhapara, Keolari, Seoni, Barghat and Kurai) of Seoni district. From the study it was observed that the highest number of medicinal plants was observed in Seoni and Barghat Tehsils (Graph 1). The traditional healers and the tribals use these plants for their medicinal importance. Out of the total number of reported plant species, plant families Fabaceae, Cucurbitaceae and Poaceae were found to be the most dominant which depicted nine and six plant species followed by Moraceae, Caesalpinaceae, Apiaceae, Malvaceae, Myrtaceace, Anacardiaceae, Solanaceae, Zingiberaceae, Oleaceae, Chenopodiaceae, Lamiaceae, Combretaceae, Apocynaceae, Arecaceae, Liliaceae, Brassicaceae and Rutaceae which showed five and less than five plant species while, plant families Asteraceae, Linaceae, Punicaceae, Cuscutaceae, Araceae, Myristicaceae, Pedaliaceae, Lythraceae, Bixaceae, Rubiaceae, Nymphaeceae, Musaceae, Magnoliaceae, Cactaceae, Meliaceae, Caricaceae, Mimosaceae, Tilaceae, Rhamnaceae, Annonaceae, Verbenaceae and Ongraceae reported single plant species (Graph 2.1-2.4).

The reported plant species are used by the traditional healers and forest dwellers for the treatment for various skin ailments. The use of medicinal plants for curing different ailments is prevalent in this region and a large number of local populations rely on this indigenous knowledge and abundantly available herbal flora. As the modern medicinal facilities and allopathic medicines are out of the reach of tribals due to their high cost and lack of availability the medicinal plants knowledge is 
transferred through generations through the traditional healers.

Ethonomedicinal documentation of medicinal plants was also carried out by Nath and Khatri (2010), the authors reported documentation of ethnomedicinal data of Chhindwara and Betul districts and uses of medicinal plants for the treatment of various diseases. Seventy seven species of medicinal plants was reported from Chhindwara district and 50 species of plants were reported from Betul district in the study. De Wet et al. (2013) studied the ethnomedicinal uses of plants found in the rural community of Northern Maputaland, South Africa for various skin disorders. The authors concluded use of nine different medicinal plant species for curing skin infections like rashes, ringworm, sores, wounds, acne, burns and boils. Gwalvanshi and Bishwas (2017) also documented ethnomedicinal plants of Balaghat district and their ethnoveterinary uses. For the study two divisions of Balaghat district were selected and field work and survey for documentation of medicinal plants was performed. The medicinal plants identified in the survey were used by the tribal people for curing different ailments of animals.

Table 1. Tabular representation of list of Medicinal plants observed in 8 Tehsils of Seoni District, Madhya Pradesh, India.

\begin{tabular}{|c|c|c|c|c|}
\hline SN. & BOTANICAL NAME & COMMON NAME & FAMILY & DISTRIBUTION \\
\hline 1. & Helianthus annuus Linn & Suryamukhi & Asteraceae & LD \\
\hline 2. & Trachyspermum ammi & Ajwain & Apiaceae & GS,DN,CP \\
\hline 3. & Daucus carota Linn var sativa & Gajar & Apiaceae & $\mathrm{KL}, \mathrm{SN}, \mathrm{BG}, \mathrm{KR}$ \\
\hline 4. & Coriandrum sativum Linn & Dhaniya & Apiaceae & $\mathrm{BG}, \mathrm{KR}, \mathrm{SN}$ \\
\hline 5. & Foeniculum vulgare Mill & Sauf & Apiaceae & BG \\
\hline 6. & Linum usitatissimum & Alsi & Linaceae & $\mathrm{BG}, \mathrm{KR}$ \\
\hline 7. & Punica granatum Linn & Anar & Punicacea & $\mathrm{BG}, \mathrm{SN}, \mathrm{KL}$ \\
\hline 8 & Clitoria ternatea Linn & Aparajita & Fabaceae & $\mathrm{CP}$ \\
\hline 9 & Cajanus cajan (L) Millsp & Arhar & Fabaceae & DN,GS,LD \\
\hline 10 & Derris indica (Lam.) Bennet & Karanj & Fabaceae & BG \\
\hline 11 & Butea monosperma Linn & Palash & Fabaceae & $\mathrm{BG}, \mathrm{KR}$ \\
\hline 12 & Lens culinaris Medik & Masur & Fabaceae & $\mathrm{CP}$ \\
\hline 13 & $\begin{array}{l}\text { Vigna radiata (Linn) wilczek } \\
\text { var.radiata verdcourt }\end{array}$ & Mung & Fabaceae & $\mathrm{KL}, \mathrm{SN}, \mathrm{BG}, \mathrm{KR}$ \\
\hline 14 & Arachis hypogea Linn & Mungfali & Fabaceae & BG \\
\hline 15 & Vigna aconitifolia Marechal & Moth & Fabaceae & $\mathrm{KL}, \mathrm{SN}, \mathrm{BG}, \mathrm{KR}$ \\
\hline 16 & Dalbergia sissoo Roxb ex dc & Sheesham & Fabaceae & $\mathrm{KR}, \mathrm{BG}, \mathrm{SN}$ \\
\hline 17 & Cuscuta reflexa Roxb & Amar bel & Cuscutaceae & $\mathrm{KR}, \mathrm{BG}$ \\
\hline 18 & Syzygium cumini (Linn) Skeels & Jamun & Myrtaceae & LD,GS,DN \\
\hline 19 & $\begin{array}{c}\text { Syzygium aromaticum (Linn) } \\
\text { merret l.m.perry }\end{array}$ & Laung & Myrtaceae & $\mathrm{CP}, \mathrm{KL}, \mathrm{SN}, \mathrm{BG}$ \\
\hline 20 & Cassia fistula Linn & Amaltas & Caesalpiniaceae & $\mathrm{KR}, \mathrm{BG}$ \\
\hline 21 & Bauhinia variegata Linn & Kachnar & Caesalpiniaceae & BG \\
\hline 22 & Delonix regia (Boj ex hook) raf & Gulmohar & Caesalpiniaceae & $\mathrm{BG}, \mathrm{KR}$ \\
\hline 23 & Senna tora (Linn) roxb & Panwar & Caesalpiniaceae & BG \\
\hline 24 & Amorphophallus paeoniifolius & Suran & Araceae & LD,GS,DN,CP \\
\hline 25 & Mangifera indica Linn & Aam & Anacardiaceae & $\mathrm{KL}, \mathrm{SN}, \mathrm{BG}, \mathrm{KR}$ \\
\hline 26 & Anacardium occidentale Linn & Kaju & Anacardiaceae & GS,DN,CP \\
\hline 27 & Solanum tuberosum Linn & Aaloo & Solanaceae & $\mathrm{KL}$ \\
\hline 28 & Lycopersicon esculentum Mill & Tamatar & Solanaceae & $\mathrm{SN}, \mathrm{BG}, \mathrm{KR}$ \\
\hline 29 & Datura metel Linn & Dhatura & Solanaceae & $\mathrm{CP}, \mathrm{KL}, \mathrm{SN}$ \\
\hline 30 & Solanum melongena Linn & Baigan & Solanaceae & BG \\
\hline 31 & Amomum subulatum Roxb & Badi Elaichi & Zingiberaceae & $\mathrm{SN}, \mathrm{BG}, \mathrm{KR}$ \\
\hline 32 & Zingiber officinale rocs. & Adrak & Zingiberaceae & BG \\
\hline 33 & Curcuma longa Linn & Haldi & Zingiberaceae & LD,GS,DN,CP \\
\hline 34 & Ficus carica Linn & Anjir & Moraceae & $\mathrm{KL}, \mathrm{SN}$ \\
\hline 35 & Artocarpus hetrophyllum Lam & Kathal & Moraceae & SN \\
\hline 36 & Morus alba Linn & Shehtut & Moraceae & $\mathrm{BG}, \mathrm{KR}, \mathrm{SN}$ \\
\hline 37 & Ficus religiosa Linn & Peepal & Moraceae & $\mathrm{SN}, \mathrm{BG}, \mathrm{KR}$ \\
\hline
\end{tabular}


Table 1 Continue

\begin{tabular}{|c|c|c|c|c|}
\hline 38 & Ficus benghalensis L. & Bargad & Moraceae & LD,GS,DN \\
\hline 39 & Anthocephalus cadamba Roxb. mig & Kadamba & Rubiaceae & $\mathrm{BG}, \mathrm{SN}$ \\
\hline 40 & $\begin{array}{l}\text { Tabernaemontana divaricata Chandni } \\
\text { (Linn) R. Br. Ex Roem \& Schult }\end{array}$ & Apocynaceae & $\mathrm{BG}, \mathrm{SN}$ & \\
\hline 41 & Catharanthus roseus (Linn) g. don & Sadapuspa & Apocynaceae & SN \\
\hline 42 & Gossypium herbaceum Linn & Kapas & Malvaceae & $\mathrm{CP}, \mathrm{KL}, \mathrm{SN}$ \\
\hline 43 & Hibiscus rosasinensis Linn & Gudhal & Malvaceae & $\mathrm{BG}, \mathrm{SN}$ \\
\hline 44 & Abelmoschus esculentus & Bhindi & Malvaceae & $\mathrm{KR}, \mathrm{SN}, \mathrm{LD}$ \\
\hline 45 & Nelumbo nucifera & Kamal & Nymphaeaceae & KR,LD \\
\hline 46 & Momordica dioica Roxb Ex . willd & Karkoti & Cucurbitaceae & SN \\
\hline 47 & Momordica dioica charantia & Karela & Cucurbitaceae & $\mathrm{SN}, \mathrm{KL}, \mathrm{CP}$ \\
\hline 48 & $\begin{array}{l}\text { Cirtullus vulgaris var. fistulosus } \\
\text { (Stocks ) Duthie \& Fuller }\end{array}$ & Tarbuj & Cucurbitaceae & SN \\
\hline 49 & Trichosanthes dioica Roxb & Parval & Cucurbitaceae & BG,GS,LD \\
\hline 50 & Lagenaria siceraria (Molina ) standl & Lauki & Cucurbitaceae & $\mathrm{BG}, \mathrm{SN}$ \\
\hline 51 & Cayaponio laciniosa (Linn ) C. Jeffery & Shivalingi & Cucurbitaceae & CP,LD,SN,BG \\
\hline 52 & Anacardium occidentale Linn & Kaju & Anacardiaceae & SN \\
\hline 53 & Saccharum spontaneum Linn & Kaans & Poaceae & SN,BG \\
\hline 54 & Desmostachya bipinnata (Linn ) stapf. & Kush & Poaceae & SN,BG,KR \\
\hline 55 & Rosa centifolia Linn & Gulab & Poaceae & LD,GS,DN \\
\hline 56 & Oryza sativa Linn & Chawal & Poaceae & $\mathrm{CP}, \mathrm{KL}, \mathrm{SN}$ \\
\hline 57 & Cynodon dactylon (Linn ) pers & Dub & Poaceae & $\mathrm{BG}, \mathrm{SN}, \mathrm{LD}, \mathrm{KL}$ \\
\hline 58 & Bambusa arundinaceae Willd & Bans & Poaceae & SN,BG \\
\hline 59 & Musa paradisiaca Linn & Kela & Musaceae & SN \\
\hline 60 & Phoenix sylvestris (Linn) Roxb & Khajur & Arecaceae & BG \\
\hline 61 & Cocos nucifera Linn & Nariyal & Arecaceae & $\mathrm{DN}, \mathrm{CP}, \mathrm{KL}$ \\
\hline 62 & Areca catechu Linn & Supari & Arecaceae & $\mathrm{BG}, \mathrm{SN}$ \\
\hline 63 & Aloe vera (Linn ) burm. . F . & Gwarpatha & Liliaceae & LD,GS,DN \\
\hline 64 & Allium cepa Linn & Pyaaz & Liliaceae & $\mathrm{CP}, \mathrm{KL}, \mathrm{SN}$ \\
\hline 65 & Allium sativum Linn & Lasun & Liliaceae & BG \\
\hline 66 & Pyrus communis Linn & Nashpati & Rosaceae & KL,LD \\
\hline 67 & Prunus amygdalus Batsch & Badam & Rosaceae & $\mathrm{DN}, \mathrm{CP}$ \\
\hline 68 & Brassica rapa Linn & Shalgam & Brassicaceae & SN \\
\hline 69 & Brassica campestris Linn & Sarso & Brassicaceae & BG \\
\hline 70 & Michelia champaca Linn & Champa & Magnoliaceae & SN,BG \\
\hline 71 & Jasminum officinale Linn & Chameli & Oleaceeae & $\mathrm{KR}$ \\
\hline 72 & Jasminum sambac (Linn) & Bela & Oleaceae & $\begin{array}{c}\mathrm{BG}, \mathrm{SN}, \mathrm{KL}, \mathrm{CP}, \\
\mathrm{DN}\end{array}$ \\
\hline 73 & $\begin{array}{c}\text { Manilkara zapota (Linn) } \\
\text { p. van royen }\end{array}$ & Chikoo & Oleaceeae & GS,DN,CP \\
\hline 74 & Beta vulgaris Linn & Chukandar & Chenopodiaceae & $\mathrm{BG}, \mathrm{SN}$ \\
\hline 75 & Spinacia oleracea Linn & Paalak & Chenopodiaceae & SN,BG \\
\hline 76 & Chenopodium album Linn & Bathua & Chenopodiaceae & $\mathrm{SN}, \mathrm{KL}, \mathrm{CP}$ \\
\hline 77 & Myristica fragrans houtt & Jaiphal & Myristicaceae & LD,GS,DN \\
\hline 78 & Sesamum indicum Linn & Til & Pedaliaceae & SN \\
\hline 79 & Ocimum sanctum Linn & Tulsi & Lamiaceae & BG,SN \\
\hline 80 & Mentha spicata Linn & Pudina & Lamiaceae & $\mathrm{KL}, \mathrm{SN}, \mathrm{BG}, \mathrm{KR}$ \\
\hline 81 & Opuntia dillenii & Nagfani & Cactaceae & LD,BG,GS \\
\hline 82 & Azadirachta indica Linn & Neem & Meliaceae & SN,BG,KL \\
\hline 83 & Murraya koenigii Linn & Meethi Neem & Rutaceae & LD,GS \\
\hline 84 & $\begin{array}{c}\text { Citrus aurantiifolia (Christm.) } \\
\text { Swingle }\end{array}$ & Nimbu & Rutaceae & BS,GS \\
\hline 85 & Aegle marmelos Linn correa & Bel & Rutaceae & $\mathrm{GS}, \mathrm{LD}, \mathrm{KL}$ \\
\hline 86 & Citrus sinensis (Linn) Osbeck & Mosumbi & Rutaceae & SN,KL,LD \\
\hline 87 & Carica papaya Linn & Papita & Caricacea & $\mathrm{KR}, \mathrm{SN}, \mathrm{KL}$ \\
\hline
\end{tabular}


Table 1 Continue

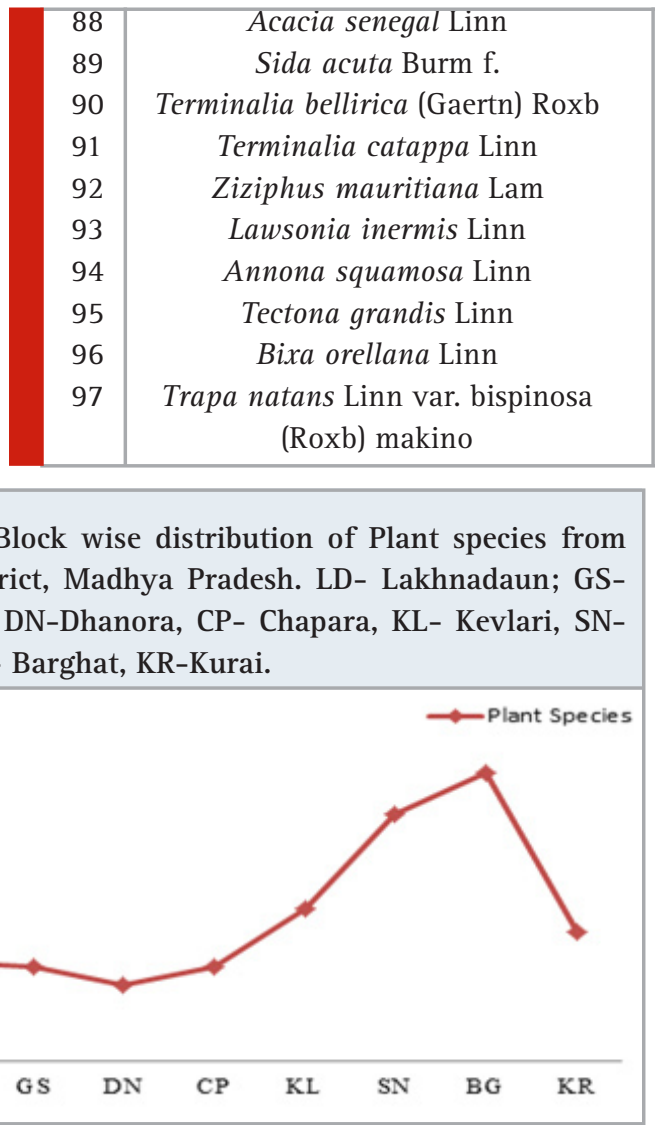

Graph 2.1: Comparative account of dominant plant families.

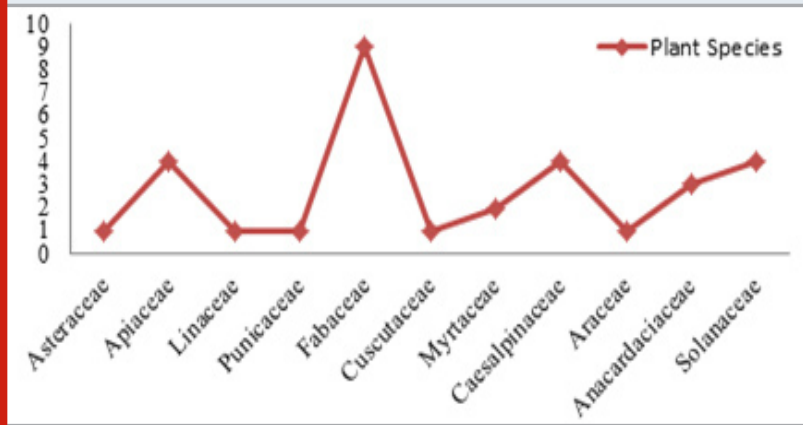

Graph 2.2: Comparative account of dominant plant families.

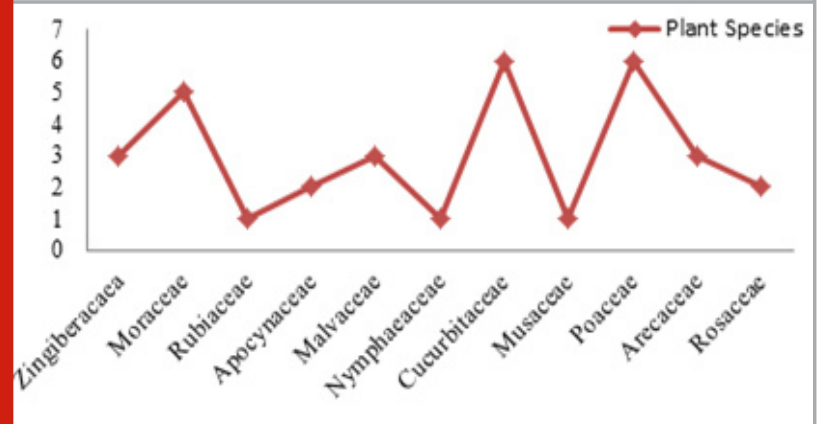

Ahirwar et al. (2017) reported survey of medicinal plants of Tikamgarh, Madhya Pradesh for the detection of plants species used by the tribal people for curing fever.

Graph 2.3: Comparative account of dominant plant families.

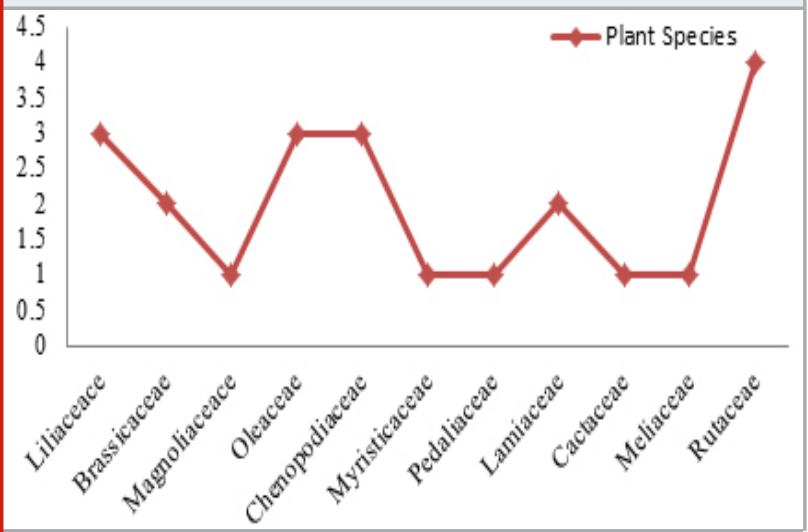

Graph 2.4: Comparative account of dominant plant families.

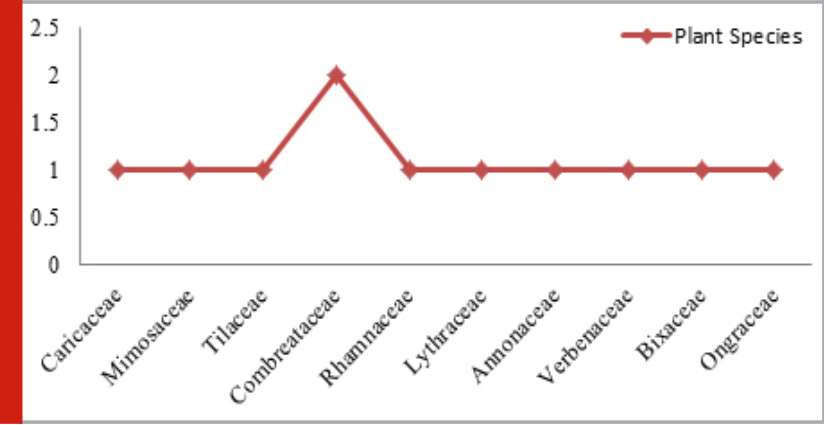

The authors highlighted 41 plant species that the tribals used for curing fever, jaundice, diarrhea, dysentery, cough and asthma. Jima and Megersa (2018) performed ethnobotanical survey for documentation of medicinal plants used by local communities of Berbere distict, South East Ethopia for the treatment of various human diseases. The authors identified 70 medicinal plants belonging to 56 genera and 46 families in the survey. Singh et al. (2020) explored the ethnobotanical diversity of Jasrota Hill in Western Himalaya region. The study was conducted to check local healing practices followed by the local dwellers of the region for the treatment of various diseases. The authors determined ethnomedicinal uses of 121 plant species belonging to 105 genera and 53 families.

The present study overviews documentation of maximum number of medicinal plant species used for preparation 
of herbal medicines by the traditional healers and tribals. Seoni district has rich herbal biodiversity which was observed in the study, the tribals and rural inhabitants of the place largely depend on this medicinal treasure to treat various ailments. Concrete measures should be taken to conserve this rich natural flora of Seoni district along with the traditional herbal medicine knowledge.

\section{CONCLUSION}

The observations and data acquired from the traditional healers in the above study indicate that the tribal people possess prominent knowledge of the medicinal plants found in the region. The fieldwork and survey of all the eight tehsils of Seoni district showed presence of prosperous biodiversity of the region with the Seoni and Barghat tehsil treasuring highest number of medicinal plant species. In the overall study, 97 plant species were documented belonging to 43 plant families with the help of the tribals and the locals of the area. Further studies related to the medicinal preparations using the herbal plants will be investigated. The study strongly supports conservation and documentation of the vast flora of the Seoni district.

\section{REFERENCES}

Ahirwar R. K. (2014). Utilization of medicinal plants by the tribes of Bhatiya, distict Shahdol, Madhya Pradesh. International Journal of Science and Research. 3(9): 149-151.

Ahirwar R. P. (2017). Ethnobotanical survey of medicinal plants commonly used by tribal person of Tikamgarh district, Madhya Pradesh. World Journal of Pharmaceutical Research. 6(7): 1085-1107.

Ahirwar R. P., Tripathi J. and Singh R. (2017). Ethnomedicinal study of plants used by tribal person for fever diseases in Tikamgarh district, (M. P.). International Journal of Botany Studies. 2(3): 64-67. Alyemeni M.N., Sher H. and Wijaya L. (2010). Some observations on Saudi medicinal plants of veterinary importance. Journal of Medicinal Plants Research.4(21): 2298-2304.

Ayyanar M. and Ignacimuthu S. (2011). Ethnobotanical survey of medicinal plants commonly used by Kani tribals in Tirunelveli hills of Western Ghats, India. Journal of Ethnopharmacology. 13(4): 851-864.

Balakrishna A. (2005). Ayurved jadi buti Rahasya. Divya Publications.

Bandyopadhyay S. (2017). Observation on the traditional herbal remedies of pain from Koch Bihar district, West Bengal. World Journal of Pharmaceutical Research. 6(16): 1497-1509.

De Wet H., Nciki S. and van Vuuren S. F. (2013). Medicinal plants used for the treatment of various skin disorders by a rural community in northern Maputaland, South Africa. Journal of Ethnobiology and Ethnomedicine. 9: 51-60.

Dwivedi S., Dwivedi A. and Dwivedi S. N. (2008). Folk lore uses of some plants by the tribes of Madhya
Pradesh with special reference to their conservation. Ethnobotanical Leaflets. 12: 763-771.

Gwalwanshi D.R. and Bishwas A. J. (2017). Documentation of ethnoveterinary medicinal flora of Balaghat district, Madhya Pradesh, India. International Journal of Research in Ayurveda and Pharmacy. 8(2): 279-284.

Hussain W., Badshah L., Ullah M., Ali M., Ali A. and Hussain F. (2018). Quantitative study of medicinal plants used by the communities residing in Koh-e-Safaid range, North Pakistani- Afhgan borders. Journal of Ethnobiology and Ethnomedicine. 14: 30.

Iqbal J. (2017). Documentation of ethno-medicinal plants used by tribes of Mandla district (M.P.) (India) for the treatment of keratinophilic infections. International Journal of Biology Research. 2(4): 67-72.

Jain M., Shrivastava P. N. and Samar R. (2018). Survey of Ethnobotanical medicinal plants used by the people of district Guna, Madhya Pradesh. International Journal of Life Science and Scientific Research. 4(4): 1880-1888. Jatav R. and Mehta R. (2013). Study of medicinal plants used in dermatological problems with special references to Sahariya tribe of Shivpuri district of Madhya Pradesh. Indian Journal of Applied Research. 3(8): 60-62.

Jima T.T. and Megersa M. (2018). Ethnobotanical study of medicinal plants used to treat human diseases in Berbere district, Bale zone of Oromia regional state, South East Ethopia. Evidence-Based Complementary and Alternative Medicine. 8602945.

Karunamoorthi K., Jegajeevanram K., Vijayalakshmi J. and Mengistie E. (2012). Traditional medicinal plants: A source of phytotherapeutic modality in resourceconstrained health care settings. Journal of EvidenceBased Complementary and Alternative Medicine. 18(1): 67-74.

Lal S. and Sahu P. K. (2019). Observation and documentation on angiosperm herbs of Balod district, Chattisgarh. International Journal of Innovative Studies in Sociology and Humanities. 4(6): 78-84.

Mohan V. R., Rajesh A., Athiperumalsami T. and Sutha S. (2008). Ethnomedicinal plants of the Tirunelveli district, Tamil Nadu, India. Ethnobotanical Leaflets. 12: 79-95.

Mukherjee A. K., Tripathi A. K., Kumar A., Singh A. N., Shukla B. K., Verma D. M., Khanna K. K., Ram Lai M. I. H., Shrivastava R. C. and Dixit R. D. (1993). Flora of Madhya Pradesh. Vol.1. Eds. Verma D. M., Balakrishnan N. P. and Dixit R. D. Botanical Survey of India.

Nath V. and Khatri P. V. (2010). Traditional knowledge on ethno-medicinal uses prevailing in tribal pockets of Chhindwara and Betul districts, Madhya Pradesh, India. African Journal of Pharmacy and Pharmacology. 4(9): 662-670.

Pal M. C. and Patel R. (2014). Ethno-medicinal plants used by tribes of bajag forest range in Dindori district of Madhya Pradesh (India). The Social ION. 3(2): 179182.

Pius O.L., Sujanapal P. and Udayan P. S. (2015). 
Observations on the medicinal plant diversity of Malappuram district of Kerala with special reference to folk and Indian systems of medicines. International Journal of Advanced Research. 3(2): 314-325.

Rahman M. H. (2013). A study on exploration of ethnobotanical knowledge of rural community in Bangladesh: Basis for biodiversity conservation. ISRN Biodiversity. 369138.

Rai R. (2016). Herbal folk remedies in cure of arthritis by ethnic communities in Madhya Pradesh, India. Asian Journal of Research in Pharmaceutical Sciences. 6(3): 177-184.

Rai R. (2017). Promising medicinal plants their parts and formulations prevalent in folk medicines among ethnic communities in Madhya Pradesh, India. Pharmacy and Pharmacology International Journal. 5(3): 99-106.

Satpute S. V. (2020). Biodiversity threat assessment of ethnomedicinal plants. International Journal of Scientific and Research Publications. 10(2): 467-473.
Sharma J., Gaur R. D., Gairola S., Painuli R. M. and Siddiqi T. 0. (2013). Traditional herbal medicines used for the treatment of skin disorders by the Gujjar tribe of sub-Himalayan tract. Indian Journal of traditional knowledge. 12(4): 736-746.

Singh B., Singh B., Kishor A., Singh S., Bhat M. N., Surmal O. and Musarella C. M. (2020). Exploring plant-based ethnomedicine and quantitative ethnopharmacology: Medicinal plants utilized by the population of Jasrota hill in Western Himalaya. Sustainability. 12: 7526.

Vendrapati R.R., Doddamani S. H., Naik R., Bharali B. K., Rath C. and Mangal A. K. (2020). Exploring the medicinal plant diversity of Hassan district, Karnataka, India. Journal of Drug Research in Ayurvedic Science. 5(2): 67-87.

Wagh V. V. and Jain A. K. (2014). Ethnomedicinal uses of underground plant parts in Jhabua district of Madhya Pradesh, India. Advances in Biological Research. 8(4): 151-156. 